\title{
Correction to: Analysis of dengue model with fractal-fractional Caputo-Fabrizio operator
}

Fatmawati ${ }^{1}$, Muhammad Altaf Khann ${ }^{2,3 *}$, Cicik Alfiniyah' ${ }^{1}$ and Ebraheem Alzahrani ${ }^{4}$

The original article can be found online at https://doi.org/10.1186/ s13662-020-02881-w

\section{"Correspondence:} muhammad.altaf.khan@tdtu.edu.vn ${ }^{2}$ Informetrics Research Group, Ton Duc Thang University, Ho Chi Minh City, Vietnam

${ }^{3}$ Faculty of Mathematics and Statistics, Ton Duc Thang University, Ho Chi Minh City, Vietnam Full list of author information is available at the end of the article

\section{Correction}

Following publication of the original article [1], the authors identified that the third affiliation in the author list is incorrect, it should be 'Faculty of Mathematics and Statistics, Ton Duc Thang University, Ho Chi Minh City, Vietnam. rather than 'Faculty of Mathematics and Statistics, Ton Duc Thang University, Universitas Airlangga, 60115 Ho Chi Minh City, Vietnam.' The original paper has been updated.

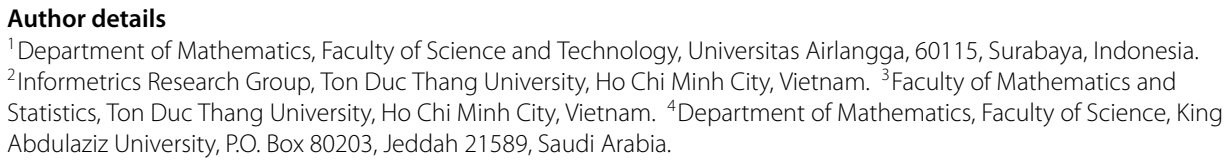

'Department of Mathematics, Faculty of Science and Technology, Universitas Airlangga, 60115, Surabaya, Indonesia. ${ }^{2}$ Informetrics Research Group, Ton Duc Thang University, Ho Chi Minh City, Vietnam. ${ }^{3}$ Faculty of Mathematics and Statistics, Ton Duc Thang University, Ho Chi Minh City, Vietnam. ${ }^{4}$ Department of Mathematics, Faculty of Science, King Abdulaziz University, P.O. Box 80203, Jeddah 21589, Saudi Arabia.

\section{Publisher's Note}

Springer Nature remains neutral with regard to jurisdictional claims in published maps and institutional affiliations.

Published online: 12 January 2021

\section{References}

1. Fatmawati, et al.: Adv. Differ. Equ. 2020, 422 (2020). https://doi.org/10.1186/s13662-020-02881-w (c) The Author(s) 2021. This article is licensed under a Creative Commons Attribution 4.0 International License, which permits use, sharing, adaptation, distribution and reproduction in any medium or format, as long as you give appropriate credit to the original author(s) and the source, provide a link to the Creative Commons licence, and indicate if changes were made. The images or other third party material in this article are included in the article's Creative Commons licence, unless indicated otherwise in a credit line to the material. If material is not included in the article's Creative Commons licence and your intended use is not permitted by statutory regulation or exceeds the permitted use, you will need to obtain permission directly from the copyright holder. To view a copy of this licence, visit http://creativecommons.org/licenses/by/4.0/. 